\title{
The Influence of Leadership, Motivation and Organization Commitment to Employee Performance in Religious Description of Religion of Tangerang Selatan City
}

\author{
Suwanto $^{1}$, Priehadi Dhasa Eka ${ }^{2}$, Randhy Agusentoso ${ }^{3}$, Muhammad Gandung ${ }^{4}$, Hafis \\ Laksmana Nuraldy $^{5}$, Imbron ${ }^{6}$, Lucia Maduningtias ${ }^{7}$, Denok Sunarsi ${ }^{8}$ \\ Department of Management, Faculty of Economic, Universitas Pamulang, Banten, \\ Indonesia
}

dosen01813@unpam.ac.id',dosen01577@unpam.ac.id²,dosen01619@unpam.ac.id², dosen02020@unpam.ac.id ${ }^{4}$,dosen02460@unpam.ac.id ${ }^{5}$,dosen02455@unpam.ac.id ${ }^{6}$, dosen01783@unpam.ac.id ${ }^{7}$,denoksunarsi@unpam.ac.id ${ }^{8}$

\begin{abstract}
This study aims to determine the effect of leadership style, motivation and organizational commitment on employee performance at the Office of Religious Affairs in South Tangerang City. The explanatory method has a sample size of 52 respondents. regression and correlation test analysis. The contribution of $35.6 \%$ of the leadership style has an effect on employee performance. Motivation has an effect on employee performance by $36.3 \%$. Organizational commitment affects employee performance by $41.8 \%$.
\end{abstract}

Keywords: Leadership Style, Motivation, Organizational Commitment, Employee Performance

\section{Introduction}

The Ministry of Religion has a very strategic position because it deals directly with the community in providing services in the field of Religious Affairs as a technical service unit. Therefore, professional, creative, proactive and productive human resources are needed, and have a high spirit of dedication with awareness and responsibility as public servants, so that the Office of Religious Affairs can carry out its functions. If the employee's performance is low, then this will result in losses both from the government side, as well as losses from the personal side of every civil servant in it.

The government has regulated the issue of the cost of weddings carried out during the working hours of the KUA and outside of the KUA and working hours, namely in Government Regulation No. 48 of 2014 which was previously an amendment from Government Regulation No. 47 of 2004. The regulation was amended and replaced so that the KUA would be more integrity and free from gratuities and to clarify the finances that the community had to pay for wedding expenses. Amendments stipulated in PP. 48 of 2014, including the multi-tariffs imposed on people who are getting married. In PP No. 48 of 2014 in article (6). From the amendments to this article, it can be seen that state revenue from the community for the cost of marriage has changed.

As stated in Law no. 25 of 2009 concerning Public Services in article 10 explains that: 1) Providers are obliged to carry out performance evaluations, Implementers within the 
organization periodically and continuously. 2) Based on the results of the evaluation as referred to in paragraph (1), the Provider is obliged to make efforts to increase the capacity of the Executor. 3) Evaluation of the executor's performance (1) shall be carried with clear and measurable indicators by taking into account the improvement of procedures and or organizational improvements in accordance with the principles of public services and laws and regulations.

Leadership is one of the factors that can make performance. One of the characteristics of a leader based on the theory of leadership traits is to have high intelligence compared to those being led. In addition, the type of leadership also affects the employees being led. One type is the autocratic type, where the leader gives orders that are enforced and must be obeyed. This certainly greatly affects the performance of employees led by this type of autocracy. According to Gaol (2014), "Human Resources are people who work and function as quantifiable (quantitative) organizational assets, and HR is the potential driving force of the organization. Human resources (HR) play a very dominant role in activities or activities. Success or not depends on the ability of human resources in carrying out the assigned tasks. "

According to Hasibuan (2016) defines "leadership style is the way a leader influences the behavior of subordinates, so that they want to work together and work productively to achieve organizational goals". Employees must be able to foster and motivate their subordinates to work together and work effectively in achieving goals. Likewise, the assessment of motivation is also very important considering thatmotivation can encourage someone to be happy to do their job well. Understanding motivation is not an easy thing, because motivation is something that is within a person and cannot be seen from the outside.

It is very important for an employee to have a commitment to the organization or company where they work, because having a high commitment will be able Windy and Gunasti (2014) "The definition of organizational commitment according to Mathins and Jackshon is the degree to which employees believe and accept organizational goals and will not leave the organization". Thus employees are very important to have organizational commitment in employees because it can support the achievement of maximum performance, work that is in accordance with their abilities and have satisfaction in the workplace, giving rise to good commitment. Likewise, the level of commitment, both the company's commitment to employees, and between employees to the company, is needed because through this commitment a professional work climate will be created.

Assessment of work evaluation is an effort to determine the condition of work performance, so that it can be seen whether there are progress and obstacles in implementing programs and activities so that they can be assessed and learned (lessons learned) for future improvements, as well as providing solutions to problems found for the purpose of improving performance and work unit accountability.

According to Hasibuan (2016) "Job appraisal is a manager's activity to evaluate employee work performance behavior and establish policies". Meanwhile, according to Rivai (2015) "Job appraisal is the process of determining a common understanding of the ways to be achieved, and the approach to managing in a short or long time". For employees, this assessment acts as feedback regarding abilities, deficiencies that are useful as future evaluations.

\section{Methods}


The population in Office of Religious Affairs in South Tangerang City 52 employees. The sampling 52 respondents. In analyzing regression and coefficient with associative research.

\subsection{Descriptive Analysis}

Table 1. Results of Descriptive Statistics

Descriptive Statistics

\begin{tabular}{cc|c|c|c|c}
\hline N & & Minimum & Maximum & Mean & Std. Deviation \\
\hline Leadership Style (X1) & 52 & 29 & 46 & 37.73 & 3.991 \\
\hline Motivation (X2) & 52 & 32 & 49 & 38.00 & 3.936 \\
\hline Organizational Commitment (X3) & 52 & 32 & 45 & 38.04 & 3.581 \\
\hline Employee Performance (Y) & 52 & 32 & 46 & 39.31 & 3.364 \\
\hline Valid N (listwise) & 52 & & & & \\
\hline
\end{tabular}

\subsection{Verification Analysis}

data verification to ensure the data collected is valid or not, so that in analyzing the data in accordance with the objectives.

\subsection{Multiple Linear Regression Analysis}

Table 2. Multiple Regression Test Results Coefficients ${ }^{\mathrm{a}}$

\begin{tabular}{|c|c|c|c|c|c|c|}
\hline \multicolumn{2}{|c|}{$\begin{array}{l}\text { Unstandardized Coefficients } \\
\text { Model }\end{array}$} & \multirow{2}{*}{$\frac{\text { B }}{8.881}$} & \multirow{2}{*}{$\begin{array}{r}\text { Std. Error } \\
3.907\end{array}$} & $\begin{array}{l}\text { Standardized } \\
\text { Coefficients } \\
\text { Beta } \\
\end{array}$ & $\mathbf{t}$ & Sig. \\
\hline \multirow{4}{*}{1} & (Constant) & & & & 2.273 & .028 \\
\hline & Leadership Style (X1) & .214 & .102 & .254 & 2.095 & .041 \\
\hline & Motivation (X2) & .231 & .103 & .271 & 2.241 & .030 \\
\hline & Organizational Commitment (X3) & .357 & .110 & .380 & 3.235 & .002 \\
\hline
\end{tabular}

a. Dependent Variable: Employee Performance (Y)

\subsection{Correlation Coefficient}

Table 3. Results of Correlation Coefficient Testing Results of Leadership Style Against Employee Performance

\section{Correlations $^{\mathbf{b}}$}

\begin{tabular}{|c|c|c|c|}
\hline Gaya Kepemimpinan (X1) & & & $\begin{array}{c}\text { Kinerja } \\
\text { Pegawai (Y) }\end{array}$ \\
\hline \multirow[t]{2}{*}{ Leadership Style (X1) } & Pearson Correlation & 1 & $.596^{* \pi}$ \\
\hline & Sig. (2-tailed) & & .000 \\
\hline Employee Performance (Y) & Pearson Correlation & $.596^{\pi-\pi}$ & 1 \\
\hline
\end{tabular}

**. Correlation is significant at the 0.01 level(2-tailed).

b. Listwise $\mathrm{N}=52$

Table 4. Results of Testing the Motivation Correlation Coefficient of Employee Performance

\section{Correlations $^{\mathbf{b}}$}




\begin{tabular}{llrr}
\hline Motivation (X2) & Pearson Correlation & 1 & $.603^{\text {N- }}$ \\
\cline { 2 - 4 } & Sig. (2-tailed) & .000 \\
\hline Employee Performance (Y) & Pearson Correlation & $.603^{*-}$ & 1 \\
\cline { 2 - 4 } & Sig. (2-tailed) & .000 &
\end{tabular}

**. Correlation is significant at the 0.01 level (2-tailed).

b. Listwise $\mathrm{N}=52$

Table 5. Results of Correlation Coefficient Testing Results of Organizational Commitment to Employee Performance

Correlations $^{b}$

\begin{tabular}{llr|r}
\hline \multicolumn{1}{c}{ Komitmen Organisasi (X3) } & & Kinerja Pegawai (Y) \\
\hline Organizational Commitment (X3) & Pearson Correlation & 1 & $.647^{\sim *}$ \\
\cline { 2 - 4 } & Sig. (2-tailed) & .000 \\
\hline Employee Performance (Y) & Pearson Correlation & $.647^{\top \uparrow}$ & 1 \\
\cline { 2 - 4 } & Sig. (2-tailed) & .000 & \\
\hline
\end{tabular}

**. Correlation is significant at the 0.01 level (2-tailed).

b. Listwise $\mathrm{N}=52$

Table 6. Results of Correlation Coefficient Testing of Leadership Style, Organizational Commitment and Motivation simultaneously on Employee Performance

Model Summary

\begin{tabular}{cc|c|c|c}
\hline Model & R & R Square & Adjusted R Square & \begin{tabular}{c} 
St $\begin{array}{c}\text { d. Error of the } \\
\text { Estimate }\end{array}$ \\
\hline 1
\end{tabular} \\
\hline $.748^{\mathrm{a}}$ & .560 & .533 & 2.300 \\
\hline
\end{tabular}

a. Predictors: (Constant), Organizational Commitment (X3), Motivation (X2), Leadership Style (X1)

\subsection{Determination Coefficient Analysis}

Table 7. The Results of Testing the Coefficient of Determination of Leadership Style on Employee Performance

\section{Model Summary}

\begin{tabular}{cc|c|cc}
\hline Model & R & R Square & A djusted R Square & $\begin{array}{c}\text { Std. Error of the } \\
\text { Estimate }\end{array}$ \\
\hline 1 & $.596^{\mathrm{a}}$ & .356 & .343 & 2.727 \\
\hline
\end{tabular}

a. Predictors: (Constant), Leadership Style (X1)

Table 8. Test Results of Motivation Determination Coefficients on Employee Performance

\begin{tabular}{lll|l|lrl}
\multicolumn{8}{c}{ Model Summary } \\
\hline \multirow{2}{*}{ Model } & R & & R Square & $\begin{array}{c}\text { Adjusted R } \\
\text { Square }\end{array}$ & $\begin{array}{c}\text { Std. Error of the } \\
\text { Estimate }\end{array}$ \\
\hline 1 & & $.603^{\mathrm{a}}$ & .363 & & .351 & 2.711 \\
\hline
\end{tabular}

a. Predictors: (Constant), Motivation (X2)

Table 9. Results of Testing the Coefficient of Determination of Organizational Commitment on Employee Performance Model Summary

\begin{tabular}{lr|r|rrr}
\hline Model & R & R Square & $\begin{array}{c}\text { A djusted R } \\
\text { Square }\end{array}$ & $\begin{array}{c}\text { Std.Error of the } \\
\text { Estimate }\end{array}$ \\
\hline 1 & & $.647^{\mathrm{a}}$ & .418 & .407 & 2.591 \\
\hline
\end{tabular}


Predictors: (Constant), Organizational Commitment (X3)

Table 10. The Results of Testing the Coefficient Model Summary

\begin{tabular}{l|c|cc}
\hline \multicolumn{1}{c|}{ Model } & R Square & $\begin{array}{c}\text { A djusted R } \\
\text { Square }\end{array}$ & $\begin{array}{c}\text { Std.Error of the } \\
\text { Estimate }\end{array}$ \\
\hline $1 \quad .748^{\mathrm{a}}$ & .560 & .533 & 2.300 \\
\hline a. Predictors: (Constant), Organizational Commitment (X3), Motivation (X2), Leadership Style (X1)
\end{tabular}

\subsection{Hypothesis Test}

\section{a) Partial Hypothesis Test (t-Test)}

Table 11. Hypothesis Test Results of Leadership Style Against Employee Performance

Coefficients $^{\mathrm{a}}$

\begin{tabular}{|c|c|c|c|c|c|c|}
\hline & ndardized Coefficients & B & Std. Error & $\begin{array}{c}\text { Standardized } \\
\text { Coefficients } \\
\text { Beta }\end{array}$ & $\mathbf{t}$ & Sig. \\
\hline$\overline{1}$ & (Constant) & 20.340 & 3.630 & & 5.603 & .000 \\
\hline & Leadership Style (X1) & .503 & .096 & .596 & 5.254 & .000 \\
\hline
\end{tabular}

a. Dependent Variable: Employee Performance (Y)

Table 12. Results of Motivation Hypothesis Test on Employee Performance

Coefficients $^{\mathrm{a}}$

\begin{tabular}{|c|c|c|c|c|c|c|}
\hline \multicolumn{4}{|c|}{ Unstandardized Coefficients } & $\begin{array}{c}\text { Standardized } \\
\text { Coefficients } \\
\text { Beta } \\
\end{array}$ & $\mathbf{t}$ & Sig. \\
\hline$\overline{1}$ & (Constant) & 19.730 & 3.684 & & 5.356 & .000 \\
\hline & Leadership Style (X1) & .515 & .096 & .603 & 5.342 & .000 \\
\hline
\end{tabular}

a. Dependent Variable: Employee Performance (Y)

Table 13. Hypothesis Test Results of Organizational Commitment to Employee Performance Coefficients $^{\text {a }}$

\begin{tabular}{|c|c|c|c|c|c|c|}
\hline Unstandardized Coefficients & ndardized Coefficients & B & Std. Error & $\begin{array}{c}\text { Standardized } \\
\text { Coefficients } \\
\text { Beta } \\
\end{array}$ & $\mathbf{t}$ & Sig. \\
\hline$\overline{1}$ & (Constant) & 16.192 & 3.870 & & 4.184 & .000 \\
\hline & Leadership Style (X1) & .608 & .101 & .647 & 5.998 & .000 \\
\hline
\end{tabular}

a. Dependent Variable: Employee Performance (Y)

b) Simultaneous Hypothesis Test (F-Test)

Table 14. Hypothesis Test Results on Leadership Style, Motivation and Organizational Commitment to Employee Performance

ANOVA $^{a}$

\begin{tabular}{llr|r|r|c}
\hline \multicolumn{1}{l}{ Model } & Sum of Squares & df & Mean Square & F & Sig. \\
\hline 1 & Regression & 323.203 & 3 & 107.73420 .369 & $.000^{\mathrm{b}}$ \\
\cline { 2 - 7 } & Residual & 253.874 & 48 & 5.289 & \\
\hline
\end{tabular}




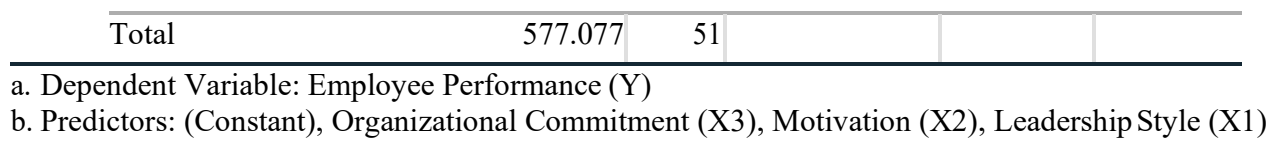

\section{Result and Discussion}

\subsection{Leadership Style on Employee Performance}

the magnitude of the correlation of 0.596 leadership style to the employee performance in the medium category with a determination of $35.6 \%$. The $t$ test is $(5,254>2,009)$. This assumption is proven that leadership style has a very crucial role in building reliable and effective employee performance. considering employee performance as a form of selfmotivation from the leadership style to be fair and wise. Management leadership style must be taken seriously that a good company can be done through employee performance.

\subsection{Motivation on Employee Performance}

The correlation motivation is 0.603 , the strong relationship is indicated by the determination value of $36.3 \%$. furthermore it was confirmed from the results of the t test that $(5.342>2.009)$ means that there is an effect. the influence of high motivation will determine performance. motivation is grown in employees both from inside and outside themselves, so that motivation will be consistent in performing maximum performance.

\subsection{Organizational Commitment on Employee Performance}

The Correlation 0.647 work commitments with a performance of $41.8 \%$ for the contribution. $\mathrm{T}$ test obtained 8,550>2,009, the influence of commitment in carrying out tasks with full responsibility and not playing. employee performance with high commitment can solve all problems within the company. any condition if good commitment will produce good performance products too, so that commitment needs to be instilled as early as possible for the responsibilities of each employee's job.

\subsection{The Influence of Leadership Style, Motivation and Organizational Commitment on Employee Performance}

Based on regression result is $\mathrm{Y}=8.881+0.214 \mathrm{X} 1+0.231 \mathrm{X} 2+0.357 \mathrm{X} 3$ shows that leadership style and motivation have an effect on employee performance. the magnitude of the strong correlation is 0.748 . a contribution of $56.0 \%$ can have a positive impact on performance, while the remaining $44.0 \%$ are other factors that are not examined. F test is obtained $(20,369>$ $2,560)$ meaning that the three variables have an effect on maximum employee performance with different respective contributions.

\section{Conclusion}

The influence of leadership style on employee performance by $35.6 \%$ contributed positively. 
Hypothesis test $\mathrm{t}$ test $(5,254>2,009)$. Furthermore, $36.3 \%$ contribution to motivation that affects employee performance in the $t$ test is obtained (5.342> 2.009). Meanwhile, organizational commitment on employee performance on a score of $41.8 \%$ for effect, the impact that occurs with the $t$ test score $(8,550>2,009)$. 56.0\% influence contribution to the three variables in improving employee performance, the remaining $44.0 \%$ has not been studied in the case of other variables. based on the results that the components in improving employee performance must always be improved to maintain good performance. As for other factors that have not been studied, it can be a recommendation for further research.

\section{References}

[1] Agusentoso, R. (2020). Pengaruh Perputaran Piutang Dan Perputaran Persediaan Terhadap Net Profit Margin Pada Perusahaan Industri Farmasi Yang Terdaftar Di Bursa Efek Indonesia Pada Tahun 2013-2017. Jurnal Ekonomi Efektif, 2(2).

[2] Aldy, H. L. N. (2020). Pengaruh Penempatan Kerja Terhadap Kinerja Karyawan Pada Yayasan Hanifa Islamic School. Jurnal Ekonomi Efektif, 2(2).

[3] Anwar Prabu Mangkunegara, “Evaluasi Kinerja SDM”. PT Refika Aditama, Bandung, 2017.

[4] Arikunto, Suharsimi (2014). "Prosedur Penelitian Suatu Pendekatan Praktek". Jakarta: Rineka Cipta.

[5] Erlangga, H. (2020). The Challenges of Organizational Communication in the Digital Era. Solid State Technology, 63(4), 1240-1246.

[6] Erlangga, H., Sifatu, . W. O., Wibisono, . D., Siagian, . A. O., Salam, . R., Mas'adi, . M., Gunartin, ., Oktarini, . R., Manik, . C. D., Nani, ., Nurhadi, . A., Sunarsi, . D., Purwanto, . A. \& Kusjono, . G. (2020) Pharmaceutical Business Competition in Indonesia: A Review. Systematic Reviews in Pharmacy, 11 (10), 617-623. doi:10.31838/srp.2020.10.92

[7] Gandung, M., \& Suwanto, S. (2020). Analisis Pengaruh Kompensasi Dan Gaya Kepemimpinan Terhadap Kinerja Karyawan Pada PT. Surya Rasa Loka Jaya Di Jakarta Barat. JENIUS (Jurnal Ilmiah Manajemen Sumber Daya Manusia), 3(3), 236-245.

[8] Gerry Dessler (2016) Human Resources Management, Prenticehall, London: International Inc. Ghozali, Imam, “Aplikasi Analisis Multivariate dengan Program SPSS”, Edisi Kelima,Badan Penerbit Undip, Semarang, 2014.

[9] Gumilar, I., Sunarsi, D. (2020). Comparison of financial performance in banking with high car and low car (Study of banks approved in the kompas 100 index for the period 2013-2017). International Journal of Psychosocial Rehabilitation. Volume 24 - Issue 7

[10] Gunartin, Siagian, . A. O., Nufus, . K., Yusuf, . N., Supratikta, . H., Maddinsyah, . A., Muchtar, . A., Sari, . W. I., Sunarsi, . D., Akbar, . I. R., Arianto, . N., Purwanto, . A., Noryani, . \& Wijoyo, . H. (2020) A Systematic Literature Review of Education Financing Model in Indonesian School. Systematic Reviews in Pharmacy, 11 (10), 638-644. doi:10.31838/srp.2020.10.96

[11] Henry Simamora (2005), Manajemen Sumber Daya Manusia, STIE YKPN Bandung.

[12] Hidayat, D., Prabowo, B., \& Anwar, S. (2020). Organizational Leadership and Conflict in Human Resource Management Review. Solid State Technology, 63(6), 1372-1381.

[13] Imam Ghozali (2017). "Aplikasi Analisis Multivariate Dengan Program SPSS”. Edisi Kelima. Semarang: Badan Penerbit Undip.

[14] Kembara, M.D, Hanny, R., Gantina, N., Kusumawati, I., Budimansyah, D., Sunarsi, D., Khoiri, A. (2020). Scientific Literacy Profile Of Student Teachers On Science For All Context. Solid State Technology. Vol. 63 No. 6

[15] Lukiastuti, Fitri, et.al (2020). The Influence of Entrepreneur's Personal Characteristics on SMES Performance Mediated by Entrepreneurial Orientation. International Journal of Psychosocial 
Rehabilitation. Volume 24 - Issue 8

[16] Maddinsyah, A., Sunarsi, D., Hermawati, R., Pranoto. (2020). Analysis of location selection effect on the user decision that influcence the success of the service business of micro, small and medium enterprise (MSME) in bandung timur region. International Journal of Advanced Science and Technology. Vol. 29 No. 06

[17] Mangkunegara, Prabu Anwar. (2016). Evaluasi Kinerja SDM. Cetakan ke tujuh, PT Refika Aditama: Bandung.

[18] Nufus, K., Supratikta, H., Muchtar, A., Sunarsi, D. (2020). Analysis of Financial Performance: Case Study of PT. X Employee Cooperative. Utopía Y Praxis Latinoamericana. Año: 25, $\mathrm{N}^{\circ}$ Extra 10, 2020, pp. 429-444

[19] Purwanto, H., Fauzi, . M., Wijayanti, . R., Awwaly, . K. U. A., Jayanto, . I., Mahyuddin, ., Purwanto, . A., Fahlevi, . M., Adinugraha, H. H., Syamsudin, . R. A., Pratama, . A., Ariyanto, . N., Sunarsi, . D., Hartuti, . E. T. K. \& Jasmani, . (2020) Developing Model of Halal Food Purchase Intention among Indonesian Non-Muslim Consumers: An Explanatory Sequential Mixed Methods Research. Systematic Reviews in Pharmacy, 11 (10), 396-407. doi:10.31838/srp.2020.10.63

[20] Santoso, Singgih (2015). "Menguasai Statistik Multivariat”. Jakarta: PT Elex Media Komputindo.

[21] Sinamo, J. (2011). Delapan Etos Kerja Profesional. Jakarta: Institut

[22] Sobarna, A., Rizal, R. M., Hambali, S., \& Sunarsi, D. (2020). Influence Make a Match Model toward Communication skills in Physical and Health Pedagogical Concept. Solid State Technology, 63(6), 1355-1363.

[23] Sobarna, A., Sunarsi, D., \& Roinadi, D. K. (2020). The Effect of Pedagogic Competence Kids Athletic toward Motivation for Elementary School. Solid State Technology, 63(6), 1364-1371.

[24] Sugiyono (2017), "Metode Penelitian Administrasi : dilengkapi dengan Metode $R$ \& D". Bandung: Alfabeta.

[25] Suhariadi, Fendy, "Manajemen Sumber Daya Manusia: Dalam Pendekatan Teoritis-Praktis", Airlangga University Press, Surabaya 2013.

[26] Suharsimi Arikunto "Prosedur Penelitian Suatu Pendekatan Praktek", PT. Rineka Cipta, Jakarta, 2013.

[27] Sunarsi, D. (2019). Seminar Sumber Daya Manusia. Tangerang Selatan: Unpam Press Sunarsi, D. (2018). Buku Ajar: Seminar Perencanaan Sumber Daya Manusia. Tangerang Selatan: Asmoro Mediatama

[28] Sunarsi, D. (2019). The Analysis of The Work Environmental and Organizational Cultural Impact on The Performance and Implication of The Work Satisfaction. Jurnal Ilmiah Ilmu Administrasi Publik, 9(2), 113-122.

[29] Sunarsi, D. (2020). The Influence of Supply Chain Strategy on Employee Performance on Small and Medium Business in Beringharjo Market, Yogyakarta- Indonesia. International Journal of Supply Chain Management. Vol. 9, No. 5

[30] Sunarsi, D., \& Kusjono, G. (2019). Pengaruh Lingkungan Kerja Non Fisik, Konflik Dan Turn Over Intention Terhadap Produktivitas Kerja Karyawan Pada CV. Usaha Mandiri Jakarta Selatan. Jurnal Ekonomi Efektif, 1(3).

[31] Sunarsi, D., Rohaeni, . N., Wulansari, . R., Andriani, . J., Muslimat, . A., Rialmi, . Z., Kustini, . E., Kristianti, . L. S., Rostikawati, . D., Effendy, . A. A., Purwanto, . A. \& Fahlevi, . M. (2020) Effect of e-Leadership Style, Organizational Commitment and Service Quality towards Indonesian School Performance. Systematic Reviews in Pharmacy, 11 (10), 472-481. doi:10.31838/srp.2020.10.71

[32] Suntoyo, Danang, "Penelitian Sumber Daya Manusia". PT Buku Seru, Jagakarsa, 2015. Suwanto, S., \& Eka, P. D. (2020). Analysis Of Leadership Style Influence, Job Motivation, 
And Compensation Towards Teacher Satisfaction On The Foundation Of Al-Hasra Bojongsari. Depok City. International Journal of Advances in Social and Economics, 2(3).

[33] Supriyadi, D., Syafitri, . L. N. H., Widodo, S. F. A., Wahidi, R., Arinta, . Y. N., Nabhan, . F., Mufid, . A., Purwanto, . A., Fahlevi, . M., Sunarsi, . D. \& Cahyono, . Y. (2020) Innovation And Authentic Leadership Of Islamic University Lectures In Faculty Pharmacy Faculty: What Is The Role Of Psychological Capital?. Systematic Reviews in Pharmacy, 11 (8), 383-393. doi:10.31838/srp.2020.8.56

[34] Suryani, N. L., Sularmi, L., Eka, P. D., Sunarsi, D., \& Maddinsyah, A. (2020). The Analysis of Career Development and Placement of Employee Performance in Pt. Global Means of Transindo in Jakarta. Solid State Technology, 63(6), 1382-1389.

[35] Syobar, K., Hardiyan, A., Romlah, O. Y., Yusup, M., \& Sunarsi, D. (2020). The Effect of Service Quality and Price on Purchase Decisions in Woodpecker Coffee in South Jakarta. Solid State Technology, 63(6), 1491-1504.

[36] Wibowo, "Manajemen Kinerja-Edisi Ketiga”, Rajawali Pers, Jakarta, 2013. 